\title{
ЧВЕРТЬСТОРІЧНА ІСТОРІЯ РОЗВИТКУ КАФЕДРИ АНЕСТЕЗІОЛОГІЇ ТА РЕАНІМАТОЛОГІЇ УКРАЇНСЬКОЇ ВІЙСЬКОВО-МЕДИЧНОЇ АКАДЕМІЇ
}

\author{
Г.П. Хитрий, Т.М. Левченко
}

Українська військово-медична академія, м. Київ, Україна

Вступ. Висвітлення основних історичних моментів становлення кафедри анестезіології та реаніматології Української військово-медичної академії за 25 років є актуальним для відтворення цілісної картини історії кафедри, етапності та періодичності її реорганізації та розвитку. Дослідження вкладу тих науково-педагогічних працівників, які стояли біля витоків створення кафедри, а також тих, хто вносив зміни в навчальний процес, узагальнюючи досвід бойових дій на сході Украӥни, і сьогодні продовжує їх справу є важливим аспектом історико-медичного дослідження.

Мета. Розглянути питання процесу становлення i розвитку кафедри анестезіології та реаніматології Украӥнської військово-медичної академії.

Матеріали та методи. Матеріалами для статті служили нормативно-правові акти, що стосуються реформування системи військово-медичної освіти, звіти про роботу кафедри. Використано історичний, аналітичний і бібліосемантичний методи.

Результати. За період свого існування кафедра анестезіології та реаніматології УВМА внесла вагомий внесок у підготовку та перепідготовку фахівців як для медичних закладів Збройних Сил Украӥни, так і для медичних закладів МОЗ України. У процесі створення кафедри був збережений науковий потенціал ї̈ співробітників, їх досвід, наукові та практичні здобутки, що дозволило за відносно короткий термін сформувати науково-педагогічний і науковий колектив кафедри, ефективно організовувати навчальний процес з слухачами Української військово-медичної академії, лікарями-анестезіологами та лікарями інших спеціальностей лікувальних закладів Міністерства оборони України, розвивати наукову, методичну $i$ виховну роботу науково-педагогічних працівників кафедри та вивести систему підготовки військових анестезіологів на якісно новий рівень. Завдяки плідній роботі співробітників кафедри відбулося 23 випуски слухачів-анестезіологів, підготовлено 191 військового лікаря-анестезіолога.

Висновки. За порівняно невеликий термін свого існування кафедра анестезіології та реаніматології УВМА внесла вагомий внесоку підготовку та перепідготовку фахівців як для Збройних Сил України, так іля інших військових формувань і лікувальних закладів України. На сьогоднішній день кафедра анестезіології та реаніматології єдина в Україні, яка здійснює післядипломну підготовку та перепідготовку військовомедичних кадрів за фахом «Анестезіологія та інтенсивна терапія» для зміцнення обороноздатності краӥни з урахуванням досвіду АТО/OOC.

Ключові слова: Українська військово-медична академія, кафедра анестезіології та реаніматології, історія.

Вступ. Після здобуття Україною незалежності та створення власних збройних сил постало питання про підготовку військово-медичних кадрів. У зв'язку з цим згідно Постанови Кабінету Міністрів України №490 від 19 серпня 1992 р. «Про реформу системи військової освіти» було сформоване Військово-медичне відділення при Українському державному медичному університеті (УДМУ). А вже з 1 вересня 1993 року розпочали підготовку військовомедичних фахівців. Серед них 6 слухачів були зараховані для навчання за фахом «Анестезіологія».

у зв'язку 3 відсутністю профільної кафедри навчання слухачів-анестезіологів здійснювалось на кафедрі анестезіології, реаніматології та медицини катастроф УдМУ і на кафедрі анестезіології та інтенсивної терапії Київського державного інституту удосконалення лікарів. Свої знання тазначний практичний досвід майбутнім військовим анестезіологам передавали: А.Ю. Дубицький, Л.П. Чепкій, А.I. Тріщинський, І.П. Шлапак, А.В. Бєляєв, Д.А. Коваль, В.П. Цертій, С.М. Ярославська, М.В. Бондар, Ф.С. Ващук, Ф.С. Глумчер, А.А. Короткоручко та інші.

Мета. Розглянути питання процесу становлення i розвитку кафедри анестезіології та реаніматології Української військово-медичної академії.

Матеріали та методи. Матеріалами для статті служили нормативно-правові акти, що стосуються реформування системи військовомедичної освіти, звіти про роботу кафедри. Використано історичний, аналітичний i бібліосемантичний методи. 
Результати дослідження та їх обговорення. Кафедра анестезіології та реаніматології Української військовомедичної академії (УВМА) була створена відповідно до Постанови Кабінету міністрів України №820 від 16 жовтня 1995 р. «Про створення Української військово-медичної академії».

31996 р. на кафедрі на постійній основі працювали кандидат медичних наук Ю.О. Поленцов, а також доктор медичних наук А.В. Старіков і Г.І. Софієнко - за сумісництвом. Після закінчення ад'юнктури у серпні 1997 року на посаду старшого викладача кафедри був призначений капітан медичної служби Г.П. Хитрий, який з вересня 1997 р. тимчасово виконував обов'язки начальника кафедри. В жовтні 1997 р. Г.П. Хитрий під керівництвом професора А.Ю. Дубицького захистив дисертацію на здобуття наукового ступеня кандидата медичних наук на тему «Анестезіологічне забезпечення та інтенсивна терапія при хірургічному лікуванні пухлин головного мозку з використанням клофеліну та гіпертонічного розчину хлориду натрія». В 2000-2001 pp. Г.П. Хитрий виконував миротворчу місію ООН у Південному Лівані на посаді начальника відділення анестезіологіїта реанімації 3 окремого інженерного батальйону. 32002 по 2009 рр. Хитрий Г.П. пройшов шлях від доцента до начальника кафедри анестезіології та реаніматології УВМА.

В 2014 р. полковник м/с Хитрий Г.П. захистив дисертацію на здобуття наукового ступеня доктора медичних наук на тему «Клініко-експериментальне обгрунтування інтенсивної терапії при гіпотермічних ушкодженнях» (науковий консультант професор В.І. Зубков). У 2015 році Хитрому Г.П. присвоєно вчене звання професора кафедри анестезіології та реаніматології.

В період 3 листопада 2017 року по березень 2018 року Хитрий Г.П. безпосередньо брав участь в антитерористичній операції,

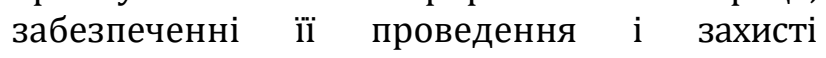
незалежності, суверенітету та територіальної цілісності України в районах проведення антитерористичної операції.

3 січня 1998 р. по жовтень 2006 р.кафедру очолював О.М. Дубов, заслужений лікар України, кандидат медичних наук, полковник медичної служби. До цього він впродовж 7 років був начальником Центру анестезіології та реанімації в Головному військовому клінічному госпіталі, активно приймав участь у педагогічній роботі, проводив заняття 3 слухачами Центральних курсів удосконалення медичного складу Збройних Сил.
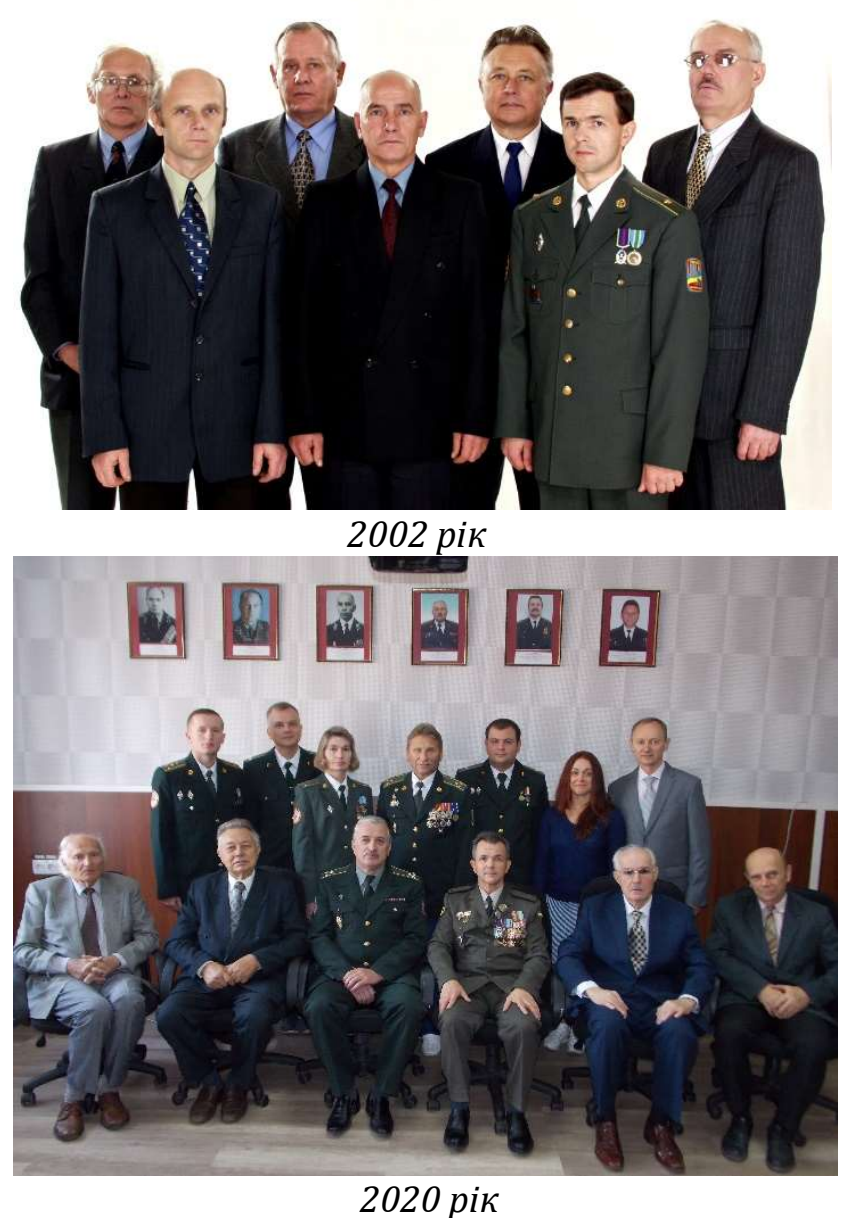

Рисунок. Науково-педагогічний персонал кафедри.

В 1996 р. під керівництвом професора A.I. Тріщинського захистив дисертацію на здобуття наукового ступеня кандидата медичних наук, тема роботи «Діагностика, патогенетична терапія та профілактика ранніх післяопераційних ускладнень у хворих міастенією після тимектомії». В 2000 р. О.М. Дубову було присвоєно вчене звання доцента.

В 1998 р. на кафедру були зараховані кандидат медичних наук М.М. Журко, професор В.А. Лісецький, а в 2000 р. - кандидат медичних наук А.В. Говенко, професор B.I. Зубков.

В 2002 р. старший лейтенант медичної служби Т.М. Левченко, випускниця УВМА за фахом «Анестезіологія», після закінчення ад'юнктури захистила дисертацію наздобуття наукового ступеня кандидата медичних наук. Тема ії роботи «Клініко-фізіологічне обгрунтування оптимальних режимів штучної вентиляції легень при лапароскопічних операціях в абдомінальній хірургії у хворих $з$ 
супутньою патологією» (науковий керівник професор А.В. Старіков). В травні 2003 р. вона була призначена на посаду старшого викладача кафедри, а у березні 2009 р. доцента кафедри. У 2011 р. Левченко Т.М. присвоєно вчене звання доцента кафедри анестезіології та реаніматології.

В 2009 р. після закінчення ад’юнктури на посаду старшого викладача кафедри був зарахований майор медичної служби B.I. Чернишов, також вихованець УВМА. В 2010 p. він захистив дисертацію на здобуття наукового ступеня кандидата медичних наук, тема його роботи «Використання плазмозамінників на основі дериватів сорбітолу для ресусцитації хворих 3 травматичним шоком» (науковий керівник професор Ф.С. Глумчер). В 2013 р. Чернишов В.І. звільнився з лав ЗС України.

У березні 2015 р. на посаду старшого викладача кафедри було зараховано підполковника медичної служби О.В. Тхоревського, який у 2014 р. захистив дисертацію на здобуття наукового ступеня кандидата медичних наук на тему «Анестезіологічне забезпечення хірургічного лікування колоректального раку у хворих 3 гіпертонічною та ішемічною хворобою» (науковий керівник - професор B.I. Зубков). В 2018 році Тхоревський О.В. звільнився 3 військової служби та продовжує працювати на кафедрі як працівник ЗСУ.

У 2018 р. на посаду старшого викладача кафедри був зарахований капітан медичної служби В.М. Мошківський, а в 2019 р. - на посаду викладача кафедри - капітан медичної служби О.В. Рабощук, також випускники УВМА. Мошківський В. і Рабощук О. є учасниками бойових дій, брали участь в антитерористичній операції, забезпеченні ії проведення i захисті незалежності, суверенітету та територіальної цілісності України в районах проведення АТО.

За період існування кафедри в навчальному процесі приймали та продовжують приймати активну участь співробітники клініки невідкладної медичної допомоги, інтенсивної терапії, анестезіології, реанімації та детоксикації Національного військово-медичного клінічного центру «ГВКГ»: полковник м/с 0.0. Бугай (начальник клініки, головний анестезіолог Медичних сил 3С України, випускник кафедри 1997 р.,), B.М. Мельник (головний анестезіолог МО України з 2005 по 2018 рр.), Г.О. Трещалін (головний анестезіолог-реаніматолог МO
України з 1995 по 2005 рр.), В.Ф. Джулай, B.I. Демідов, В.Ю. Хіль, Р.М. Кішко, М.І. Бойко (випускник кафедри 1996 р.), лікаранестезіолог В.М. Поліщук. До педагогічної роботи також залучались: С.А. Крейдич начальник відділення анестезіології та реанімації Центрального госпіталю МВС України, А.М. Циба - завідувач відділу анестезіології і інтенсивної терапії Інституту травматології та ортопедії АМН України, нині - доцент кафедри за сумісництвом, М.В. Нацюк - директор учбово-тренувального центру УНПЦ ЕМД і МК, Н.П. Ісаєнко - завідувач ВРІТ Київського центру термічної травми та пластичної хірургії.

За час існування УВМА відбулося 23 випуски слухачів-анестезіологів, підготовлено 191 військового лікаря-анестезіолога. Гордістю кафедри $\epsilon$ випускники анестезіологи, які закінчили УВМА з золотою медаллю: О.А. Зачепа (2000 р.), Савельєв С.О. (2004 р.), Бабій В.Ю. (2007 р.), Рабощук О.В. (2017 р.), Хухлей В.О. (2020р.).

Військові анестезіологи брали участь у миротворчих місіях: 0.0. Бугай - на посаді начальника ВАР 240 батальйону в Югославії 1999 рік. С.I. Півторан - начальником BAPIT 3 ОІБ в Лівані (2002 р.), начальником ВАРІТ 52 ОМБ 5 ОМБр в Республіці Ірак (2004 p.). A.I. Родзоняк - начальником ВАРІТ 51 ОМБ 5 ОМБр в Республіці Ірак (2003-2004 рр.), лікарем медичної групи 56 окремого вертолітного загону в Ліберії (2004-2005 рр.), лікареманестезіологом МП у складі Литовської групи відновлення провінції Гор в Ісламській Республіці Афганістан (2007р., 2010-2012 рр.). Д.С. Кучумов - начальником ВАІР 62 ОМБ (2004 р.), начальником BAIP 81 тактичної групи $(2005$ р.) в Республіці Ірак, лікареманестезіологом МП у складі Литовської групи відновлення провінції Гор в Ісламській Республіці Афганістан (2008-2009 рр.). С.М. Мороз - лікарем-анестезіологом МП у складі Литовської групи відновлення провінції Гор в Ісламській Республіці Афганістан (2007-2008 рp.). В.М.Добровольський анестезіологом МП у складі Литовської групи відновлення провінції Гор в Ісламській Республіці Афганістан (2010 р.). В.В. Бондаренко - начальником ВАРІТ 52 ОМБ 5 ОМБр в Республіці Ірак (2003-2004 рр.), лікарем-анестезіологом військового польового шпиталю 2 рівня у складі Польського контингенту в Ісламській Республіці Афганістан (2011-2012 рр.). 
Подолян Ю.В. - лікарем-анестезіологом МП у складі Литовської групи відновлення провінції Гор в Ісламській Республіці Афганістан (20122013 pp.).

Майже всі військові анестезіологи брали участь в забезпеченні проведення антитерористичної операції, захисті незалежності, суверенітету та територіальної цілісності України в районах проведення АТО та Операції об’єднаних сил.

В даний час штат кафедри анестезіології та реаніматології складається з 10 осіб, з яких 9 чоловік - науково-педагогічний склад і 1 посада завідувача навчальним кабінетом. На постійній основі на кафедрі працюють військовослужбовці: полковник м/с, доктор медичних наук, професор Г.П. Хитрий, підполковник м/с, кандидат медичних наук, доцент Т.М. Левченко, майор м/с В.М. Мошківський і капітан м/с О.В. Рабощук, а також працівники 3СУ: доктор медичних наук, професор В.А. Лісецький, кандидат медичних наук О.В. Тхоревський. Влітку цього року звільнився кандидат медичних наук, доцент А.В. Говенко, який працював на кафедрі з 2000 року. В навчальному процесі приймають участь викладачі кафедри за сумісництвом: доктор медичних наук, професор А.В.Старіков, кандидат медичних наук, доцент М.М. Журко, кандидат медичних наук Р.М. Кішко, кандидат медичних наук А.М. Циба, I.О. Бариська, В.В. Петриченко, а також ад'юнкт кафедри капітан м/с Ю.Д. Ухач.

Полковник медичної служби Г.П. Хитрий $\epsilon$ членом ревізійної комісії Асоціації анестезіологів України.

Доктор медичних наук, професор В.А. Лісецький $є$ членом президіума Асоціації анестезіологів України, а також Європейської асоціації по гомеостазу. Підготував 4 докторів і 17 кандидатів медичних наук.

Доктор медичних наук, професор Старіков A.В. $\epsilon$ членом спеціалізованої вченої ради по захисту кандидатських i докторських дисертацій за фахом "Гематологія та трансфузіологія" при ДУ «Інститут гематології та трансфузіології» НАМН України; член Українського наукового медичного товариства гематологів та трансфузіологів; медичний експерт по анестезіології та інтенсивній терапії при ДУ «Головне бюро Судово-медичної експертизи МОЗ України»; медичний експерт 3 медичної експертизи лікарських препаратів для анестезіології та інтенсивної терапії ДП «Державний фармакологічний центр» М03 України.
Підготував 8 кандидатів медичних наук.

На базі кафедри з 1998 року проводяться передатестаційні цикли та курси тематичного удосконалення для лікарів i молодших спеціалістів 3 медичною освітою за актуальними проблемами анестезіології та інтенсивної терапії.

32004 року відкрита підготовка в інтернатурі та вторинна спеціалізація за спеціальністю «Анестезіологія».

З 2014 року у зв'язку зі збройним конфліктом на Сході України співробітники кафедри проводять 3 мобілізованими медичними працівниками допідготовку 3 питань військової анестезіології.

В даний час співробітники кафедри проводять підготовку з питань анестезіології, реаніматології, інтенсивної терапії та медицини невідкладних станів при викладанні 42 дисциплін.

Кафедра здійснює підготовку військових анестезіологів-магістрів, проводить перепідготовку та підвищення кваліфікації анестезіологів, лікарів інших спеціальностей і медичних сестер. За весь період існування кафедри пройшли підготовку 3 питань анестезіології, реаніматології та інтенсивної терапії 241 лікар-хірург і 528 лікарів загальної практики факультету підготовки військових лікарів. На факультеті перепідготовки та підвищення кваліфікації УВМА проводяться 3 цикли спеціалізації для лікарів і медичних сестер-анестезистів, передатестаційний цикл для лікарів-анестезіологів і лікарів медицини невідкладних станів, 8 циклів тематичного удосконалення для різних категорій слухачів. На даний час пройшли спеціалізацію 103 лікаря та 324 медичні сестри-анестезисти. Перепідготовку на передатестаційному циклі з «Анестезіології» пройшли 848 лікарів, на циклах тематичного удосконалення - 353 лікаря-анестезіолога і 412 медичних сестеранестезистів. По дисципліні «Інтенсивна терапія та реаніматологія» навчалося 193 лікаря загальної практики факультету перепідготовки та підвищення кваліфікації. 3 2017 року на кафедрі здійснюється підготовка клінічних ординаторів. Першими клінічними ординаторами кафедри стали майор м/с B.M. Шевчук, майор м/с Я.В. Андронов. У 2020 році успішно закінчили клінічну ординатуру підполковник м/с I.I. Ремень, майор м/с М.C. Адамчук і майор м/с А.Т. Слободянюк.

$$
\text { Кафедрою анестезіології та }
$$

реаніматології активно враховувався досвід бойових дій на сході України. 
Так, розроблена навчальна програма тематичного удосконалення лікарів «Невідкладна медична допомога при бойовій травмі за стандартами ATLS (Advanced Trauma Life Support) та DCR (Damage Control Resuscitation)»- 108 годин.

Внесені наступні зміни до навчальної програми підготовки військових лікарів ФПВЛ “Анестезіологія та інтенсивна терапія" для лікарів-анестезіологів, а саме:

до розділу «Анестезія та інтенсивна терапія при патології нервової системи» теми «Особливості анестезіологічного забезпечення при нейрохірургічних операціях на етапах медичної евакуації з використанням досвіду АTO/OOC»; «Клініка, діагностика та IT невідкладних станів при патології нервової системи з використанням досвіду АТО/ООС»;

до розділу «Організація невідкладної медичної допомоги при надзвичайних ситуаціях» теми «Основні принципи організації екстреної медичної допомоги при масовому поступленні потерпілих 3 використанням досвіду АТО/ООС. Місце і роль лікаря-анестезіолога в роботі спеціалізованих медичних бригад»; «Поняття про крашсиндром, клініка, діагностика та IT. Особливості надання допомоги при вогнепальних і мінно-вибухових пораненнях, комбінованій травмі з використанням досвіду ATO/OOC»;

до розділу «Військова анестезіологія» теми «Організація анестезіологічної та реаніматологічної допомоги в військовопольових умовах з використанням досвіду АТО/ООС»; «Організація медичного забезпечення Збройних Сил на особливий період. Поняття про етапи медичної евакуації, види медичної допомоги, рівні медичного забезпечення та обсяги медичної допомоги, що надаються медичною службою Збройних Сил України. Принципи організації, зміст і матеріальне забезпечення анестезіологічної та реаніматологічної допомоги у військовопольових умовах. Варіанти розгортання медичних підрозділів у військово-польових умовах. Загальна характеристика сучасної бойової травми. Концепція забезпечення анестезіологічної та реаніматологічної допомоги в військово-польових умовах. Організація інфузійно-трансфузійної терапії у військово-польових умовах. Характеристика та зміст інфузійно-трансфузійних засобів. Характеристика та обсяг реаніматологічної допомоги на етапах медичної евакуації. Матеріальне оснащення для надання реаніматологічної допомоги»; «Організація анестезіологічної та реаніматологічної допомоги на етапі кваліфікованої медичної допомоги з використанням досвіду АТО/ООС»;

«Характеристика та обсяг кваліфікованої медичної допомоги. Організація, вимоги i матеріально-технічне забезпечення анестезіологічної допомоги та IT при масовому поступленні поранених. Варіанти розгортання медичної роти, військового мобільного госпіталю. Матеріальне оснащення для надання анестезіологічної та реаніматологічної допомоги на етапі кваліфікованої медичної допомоги. Характеристика методів і видів анестезії при виконанні термінових хірургічних втручань, післяопераційна IT. Задачі та компоненти протишокової терапії у поранених і потерпілих. Характеристика і зміст засобів для проведення інфузійно-трансфузійної та антибактеріальної терапії на етапах медичної евакуації»; «Організація анестезіологічної та реаніматологічної допомоги на етапі спеціалізованої медичної допомоги 3 використанням досвіду АТО/ООС. Характеристика та обсяг спеціалізованої медичної допомоги. Організація, вимоги i матеріально-технічне забезпечення для надання анестезіологічної та реаніматологічної допомоги на етапі спеціалізованої медичної допомоги. Особливості інтенсивної терапії притермічних ураженнях і синдромі тривалого стиснення. Проведення інфузійно-трансфузійної та антибактеріальної терапії при наданні спеціалізованої медичної допомоги пораненим і постраждалим»;

до розділу «Анестезія та інтенсивна терапія при термічній травмі» теми «Особливості анестезії та інтенсивної терапії при опіках. Класифікація опіків. Механізм ушкодження тканин при різних видах опіків. Патогенез, клініка, діагностика та IT опікової хвороби і опікового шоку з використанням досвіду АТО/ООС. Вибір методу анестезії при перев'язках та операціях у потерпілих 3 опіками з використанням досвіду АТО/ООС. Особливості анестезіологічного забезпечення при опіковій хворобі та опіковому шоці, післяопераційна IT. Ускладнення опіків, опікова інтоксикація: клініка, діагностика, IT. Електротравма. Сонячний і тепловий удари. Класифікація. Діагностика. Клінічна картина. Особливості невідкладної допомоги та IT»; « Місцева та загальна холодова травма, загальне переохолодження: причини виникнення, 
патогенетичні механізми, клініка, діагностика, особливості невідкладної допомоги та IT 3 використанням досвіду ATO/OOC»;

до розділу «Анестезія та інтенсивна терапія при патології нирок» тему «Особливості анестезіологічного забезпечення при ушкодженнях органів сечовивідної системи 3 використанням досвіду АТО/ООС. Клініка, діагностика та IT невідкладних станів при патології нирок і сечовивідних шляхів з використанням досвіду ATO/OOC»;

до розділу «Анестезія та інтенсивна терапія при патології травного каналу» теми «Особливості анестезіологічного забезпечення при ушкодженнях органів шлунковокишкового тракту з використанням досвіду АТО/ООС»; «Клініка, діагностика та IT невідкладних станів при патології органів травного каналу 3 використанням досвіду ATO/OOC»;

до розділу «Анестезія та інтенсивна терапія при патології серцево-судинної системи» тему «Інтенсивна терапія різних видів шоку. Особливості інтенсивної терапії шокових станів у поранених. Клініка та діагностика шокових станів, що можуть розвиватися у поранених. Інтенсивна терапія шокових станів у поранених з використанням досвіду АТО/ООС»;

до розділу «Принципи організації анестезіологічної служби $і$ інтенсивної терапї̈» тему «Розвиток і становлення анестезіології та реаніматології як науки i клінічної спеціальності. Принципи організації анестезіологічної та реаніматологічної служби. Організація анестезіологічної та реаніматологічної допомоги в армії і на флоті у мирний час та на особливий період 3 використанням досвіду АТО/ООС».

Внесені наступні зміни до навчальної програма підготовки військових лікарів ФПВЛ 3 навчальної дисципліни «Реаніматологія та інтенсивна терапія» для лікарів загальної практики - сімейної медицини, а саме доповнено темами: «Шокові стани. Особливості інтенсивної терапії шокових станів у поранених з використанням досвіду АТ0/ООС»; «Гостра дихальна недостатність. Особливості надання невідкладної допомоги пораненим при дихальних розладах 3 використанням досвіду АТО/ООС»; «Термічні ураження. Клініка, особливості перебігу, принципи IT та реанімації опікового шоку 3 використанням досвіду АТО/ООС»; «Місцева і загальна холодова травма, загальне переохолодження: причини виникнення, клініка, діагностика, принципи лікування 3 використанням досвіду АТО/ООС».

Внесені наступні зміни до навчальної програма підготовки військових лікарів ФПВЛ 3 навчальної дисципліни «Анестезіологія, реаніматологія та інтенсивна терапія в хірургії» для лікарів-хірургів, а саме доповнено темами: «Загальні питання анестезіології. Підготовка хворих і постраждалих до операції при ургентних втручаннях (перитоніт, панкреатит, кишкова непрохідність, шлунково-кишкова кровотеча) i травмах 3 використанням досвіду АТО/ООС. Особливості проведення анестезії. Можливі ускладнення, їх профілактика та лікування»; «Загальні питання реаніматології таінтенсивної терапії. Поняття про реаніматологію. Суть і методи сучасної інтенсивної терапії. Загальні принципи організації служби реанімації та інтенсивної терапії з використанням досвіду ATO/OOC. Основні методи реанімації та IT (інтубація трахеї, пункція та катетеризація трахеї, трахеостомія, ШВЛ, непрямий та прямий масаж серця, пункція серця, дефібриляція серця, катетеризація центральних i периферичних вен). Моніторинг в IT»; «Реанімація та інтенсивна терапія різних видів шоку. Класифікація, патогенез, клінічні ознаки шокових станів. Основні принципи лікування. Травматичний і геморагічний шок. Особливості клініки, реанімація та IT 3 використанням досвіду АТО/OОС. Клініка, особливості перебігу, принципи IT та реанімації постраждалих 3 опіковим шоком i холодовою травмою 3 використанням досвіду АТО/ООС. Особливості інтенсивної терапї шокових станів у поранених в використанням досвіду ATO/OOC»; «Інтенсивна терапія невідкладних станів. Особливості надання невідкладної допомоги у поранених при критичних станах 3 використанням досвіду АТО/ООС».

З 2020 року співробітники кафедри у зв'язку 3 карантинними заходами, пов'язаними з COVID-19, розпочали навчання за дистанційною формою.

У перспективі на кафедрі планується створення класу симуляційного навчання лікарів і середнього медичного персоналу для відпрацювання практичних навичок алгоритму проведення серцево-легеневої реанімації, надання екстреної медичної допомоги при політравмі, бойовій травмі та інших критичних станах. Також у найближчій 
перспективі $\epsilon$ започаткування проведення циклів тематичного удосконалення для лікарів і молодших спеціалістів з медичною освітою за дистанційною формою навчання 3 актуальних питань анестезіології та інтенсивної терапії.

Значну увагу колектив кафедри приділяє науковій роботі. Співробітники кафедри $\epsilon$ авторами численних наукових праць, запрошуються до участі як доповідачі на Всеукраїнські та міжнародні наукові заходи та регулярно беруть участь у роботі наукових, науково-практичних конференцій, конгресів, симпозіумів, майстер-класів та вебінарів по анестезіології та інтенсивній терапії. За весь період існування на кафедрі захищено 4 кандидатські дисертації, видано 6 навчальних посібників, збірник тестових завдань, 5 методичних рекомендацій, опубліковано більше 300 наукових праць. Отримано 8 патентів України на винаходи і корисні моделі та 27 посвідчень на раціоналізаторські пропозиції.

Основні наукові напрями роботи кафедри: -оптимізація анестезіологічного забезпечення та інтенсивної терапії $\mathrm{y}$ постраждалих 3 політравмою, вогнепальними і мінно-вибуховими пошкодженнями;

-анестезіологічне забезпечення та інтенсивна терапія при термічній травмі, при захворюваннях крові, патології ендокринних органів;

\section{Висновки}

1. Кафедра анестезіології та реаніматології Української військово- медичної академії за 25 років свого існування пройшла нелегкий шлях становлення та розвитку. В організації кафедри брали участь відомі фахівці з кафедри анестезіології, реаніматології і медицини катастроф Українського державного медичного університету (нині Національний медичний університет імені 0.0. Богомольця) та кафедри анестезіології і інтенсивної терапії Київського державного інституту удосконалення лікарів (нині Національна медична академія післядипломної освіти імені П.Л. Шупика).

2. Кафедрою анестезіології та реаніматології активно враховується досвід

\section{Література}

1. Постанова Кабінету Міністрів України «Про реформу системи військової освіти» № 490 від 19.08.1992 p. -інтенсивна терапія при поліорганній недостатності;

-анестезіологічне

забезпечення, інтенсивна терапія та лікування болю в онкологічних хворих;

-оптимізація виконання регіонарних методів знеболення за допомогою УЗДконтролю.

Наразі на кафедрі затверджена та виконується науково-дослідна робота «Розвиток методологічних основ прогнозування та профілактики ускладнень у військовослужбовців в периопераційному періоді в закладах охорони здоров'я в системі Міністерства оборони України», терміни виконання 2019-2020 pр, науковий керівник доктор медичних наук, професор, полковник м/с Г.П. Хитрий.

На даний час на кафедрі виконується дисертаційне дослідження на здобуття наукового ступеня «доктора філософії».

Таким чином, за порівняно невеликий термін свого існування кафедра анестезіології та реаніматології УВМА внесла вагомий внесок у підготовку та перепідготовку фахівців як для Збройних Сил України, так і для інших військових формувань і лікувальних закладів України. 3 нагоди 25-річчя 3 дня створення колектив кафедри висловлює глибоку повагу та щиру вдячність всім колишнім і теперішнім спеціалістам, які своєю наполегливою працею допомогли створити кафедру і сприяють їі становленню та подальшому розвитку.

бойових дій на сході України шляхом внесення змін і доповнень до навчальних програм, наприклад, «Невідкладна медична допомога при бойовій травмі за стандартами ATLS (Advanced Trauma Life Support) та DCR (Damage Control Resuscitation), організація анестезіологічної та реаніматологічної допомоги в військово-польових умовах 3 використанням досвіду АТО/ООС тощо.

3. На сьогоднішній день кафедра є єдиною в Україні, яка здійснює післядипломну підготовку та перепідготовку військовомедичних кадрів за фахом «Анестезіологія та інтенсивна терапія» для зміцнення обороноздатності країни.

2. Постанова Кабінету Міністрів України «Про створення Української військово-медичної академії» № 820 від 16.10.1995 р. 
3. Дубов О.М., Журко М.М., Хитрий Г.П. Історія кафедри анестезіології та реаніматології Української військово-медичної академії // Військова медицина України. - 2002. - №4, том 2. C. 58-63.

\section{References}

1. Resolution of the Cabinet of Ministers of Ukraine «On the reform of the military education system» № 490 of 19.08 .1992 «- Retrived on 03.08.2020. - Access mode: https://zakon.rada.gov.ua/laws/show/490-92$\%$ D0\%BF\#Text

2. Resolution of the Cabinet of Ministers of Ukraine «On the establishment of the Ukrainian Military Medical Academy» № 820 of 16.10.1995 - Retrived on 03.08.2020. - Access mode: https://zakon.rada. gov.ua/laws/show/820-95-\%D0\%BF\#Text
4. Хитрий Г.П., Левченко Т.М., Говенко А.В. Історія становлення та розвитку кафедри анестезіології та реаніматології Української військово-медичної академії // Військова медицина України. - 2007. - №4, том 7. - С.49-52.

3. Dubov, O.M., Zhurko, M.M., Khytryi, H.P. (2002). History of the Department of Anesthesiology and Intensive Care of the Ukrainian Military Medical Academy. Military Medicine of Ukraine. 2. (4) 58-63.

4. Khytryi, H.P., Levchenko, T.M., Hovenko, A.V. (2007). History of formation and development of the Department of Anesthesiology and Intensive Care of the Ukrainian Military Medical Academy. Military Medicine of Ukraine. 7.(4).49-52.

\section{ЧЕТВЕРТЬСТОЛЕТНЯЯ ИСТОРИЯ РАЗВИТИЯ КАФЕДРЫ АНЕСТЕЗИОЛОГИИ И РЕАНИМАТОЛОГИИ УКРАИНСКОЙ ВОЕННО-МЕДИЦИНСКОЙ АКАДЕМИИ}

\section{Г.П. Хитрый, Т.Н. Левченко}

Украинская военно-медицинская академия, г. Киев, Украина

Введение. Освещение основных исторических моментов становления кафедры анестезиологии и реаниматологии Украинской военно-медицинской академии за 25 лет является актуальным для воссоздания целостной картины истории кафедры, этапности и периодичности ее реорганизации и развития. Исследование вклада тех научно-педагогических работников, которые стояли у истоков создания кафедры, а также тех, кто вносили изменения в учебный процесс, обобщая опыт боевых действий на востоке Украины, и сегодня продолжают их дело является важным аспектом историко-медицинского исследования.

Цель. Рассмотреть вопрос процесса становления и развития кафедры анестезиологии и реаниматологии Украинской военно-медицинской академии.

Материалы и методы. Материалами для статьи послужили нормативно-правовые акты, касающиеся реформирования системы военно-медицинского образования, отчеты о работе кафедры. Использованы исторический, аналитический и библиосемантический методы.

Результаты. За период своего существования кафедра анестезиологии и реаниматологии УВМА внесла весомый вклад в подготовку и переподготовку специалистов как для медицинских учреждений Вооруженных Сил Украины, так и для медицинских учреждений МЗ Украины. В процессе создания кафедры был сохранен научный потенциал ее сотрудников, их опыт, научные и практические достижения, что позволило за относительно короткий срок сформировать научно-педагогический и научный коллектив кафедры, эффективно организовывать учебный процесс со слушателями Украинской военно-медицинской академии, врачами-анестезиологами и врачами других специальностей лечебных учреждений Министерства обороны Украины, развивать научную, методическую и воспитательную работу научнопедагогических работников кафедры и вывести систему подготовки военных анестезиологов на качественно новый уровень. Благодаря плодотворной работе сотрудников кафедры состоялось 23 выпуска слушателей-анестезиологов, подготовлено 191 военных врачей-анестезиологов.

Выводы. За сравнительно небольшой срок своего существования кафедра анестезиологии и реаниматологии УВМА внесла весомый вклад в подготовку и переподготовку специалистов как для Вооруженных Сил Украины, так и для других военных формирований и лечебных учреждений Украины. На сегодняшний день кафедра анестезиологии и реаниматологии единственная в Украине, которая осуществляет последипломную подготовку $u$ переподготовку военно-медицинских кадров по специальности «Анестезиология и интенсивная терапия» для укрепления обороноспособности страны с учетом опыта АТО/OOC.

Ключевые слова: Украинская военно-медицинская академия, кафедра анестезиологии и реаниматологии, история. 


\title{
A QUARTER CENTURY OF THE ANESTHESIOLOGY AND INTENSIVE CARE DEPARTMENT'S HISTORY IN UKRAINIAN MILITARY MEDICAL ACADEMY
}

\author{
G.P. Khytryi, T.M. Levchenko
}

Ukrainian Military Medical Academy, Kyiv

Introduction. Coverage of the main historical moments of the Department of Anesthesiology and Intensive Care of the Ukrainian Military Medical Academy for 25 years is relevant for the reproduction of a holistic picture of the history of the department, stages and periodicity of its reorganization and development. The study of the contribution of those scientific and pedagogical workers who stood at the origins of the department, as well as those who made changes in the educational process, summarizing the experience of hostilities in eastern Ukraine, and today continues their work is an important aspect of historical and medical research.

The purpose of work. To consider the issues of the process of formation and development of the Department of Anesthesiology and Intensive Care of the Ukrainian Military Medical Academy.

Materials and methods. The materials for the article were legal acts related to the reform of the military medical education system, reports on the work of the department. Historical, analytical and bibliosemantic methods were used.

Results. During existence, the Department of Anesthesiology and Intensive Care UMMA has made a significant contribution to the training and retraining of specialists for both medical institutions of the Armed Forces of Ukraine and medical institutions of the Ministry of Health of Ukraine. In the process of creating department the scientific potential of its employees, their experience, scientific and practical achievements were preserved, which allowed forming the faculty and staff and scientific team of the department in a relatively short time, to effectively organize the educational process with students of the Ukrainian Military Medical Academy, anesthesiologists, and doctors of other specialties of medical institutions of the Ministry of Defense of Ukraine, to develop scientific, methodical and educational work of faculty and staff of the department and to bring the system of military anesthesiologists training to a qualitatively new level. Thanks to the fruitful work of the staff of the department there were 23 graduations of anesthesiologists, 191 military anesthesiologists were trained.

Conclusions. For a relatively short period of its existence, the Department of Anesthesiology and Intensive Care UMMA has made a significant contribution to the training and retraining of specialists for the Armed Forces of Ukraine and for other military formations and medical institutions of Ukraine. Today, the Department of Anesthesiology and Intensive Care is the only one in Ukraine that provides postgraduate training and retraining of military medical personnel in the specialty «Anesthesiology and Intensive Care» to strengthen the country's defense capabilities based on lessons learned from ATO/JFO.

Key words: Ukrainian Military Medical Academy, Department of Anesthesiology and Intensive Care, History.

Конфлікт інтересів відсутній.

Conflicts of interest: authors have no conflict of interest to declare.

Відомості про авторів:

Хитрий Г.П., A C D E F полковник медичної служби, доктор медичних наук, професор, начальник кафедри анестезіології та реаніматології Української військово-медичної академії, м. Київ, Україна;

Левченко Т.М., А в Е підполковник медичної служби, кандидат медичних наук, доцент, доцент кафедри анестезіології та реаніматології Української військово-медичної академії, м. Київ, Україна.

$A$ - концепція та дизайн дослідження; B - збір даних; C - аналіз та інтерпретація даних; D написання статmi; $E$ - редагування статmi; $F$ - остаточне затвердження статті.

Сведения об авторах:

Хитрый Г.П., полковник медицинской службы, доктор медицинских наук, профессор, начальник кафедры анестезиологии и реаниматологии Украинской военно-медицинской академии, г. Киев, Украина;

Левченко Т.Н., подполковник медицинской службы, кандидат медицинских наук, доцент, доцент кафедры анестезиологии и реаниматологии Украинской военно-медицинской академии, г. Киев, Украина.

Information about authors:

Khytryi G.P., A C D E F Col. MS, MD DSc, Prof., Head of the Department of Anesthesiology and Intensive Care of the Ukrainian Military Medical Academy, Kyiv, Ukraine. https://orcid.org/0000-0002-7888-1771;

Levchenko T.M., A B E LtC. MS, MD PhD, Assoc. Prof., Associate Professor of the Department of Anesthesiology and Intensive Care of the Ukrainian Military Medical Academy, Kyiv, Ukraine. https://orcid.org/0000-0003-0451-9849.

$A$ - research concept and design; $B$ - collection and/or assembly of data; $C$ - data analysis and interpretation; $D$ - writing the article; $E$ - critical revision of the article; $F$ - final approval of the article.

Адреса для листування: вул. Московська, 45/1, буд. 33, м. Київ 01015 